\title{
Editorial
}

\section{Industrial pharmaceutical scenario}

\author{
A.G. Nerkar $1,2,3, *$ \\ ${ }^{1}$ Dept. of Medicinal Chemistry and Pharmacology, Parul Institute of Pharmacy \& Research, Parul University, Vadodara, \\ Gujarat, India \\ ${ }^{2}$ Founder and Director, Ateos Foundation of Science Education and Research, Pune, Maharashtra, India \\ ${ }^{3}$ Founder and Director, Carolene Therapeutics, Pvt. Ltd., Aurangabad, Maharashtra, India
}

\section{A R T I C L E I N F O}

\section{Article history:}

Received 06-02-2022

Accepted 12-02-2022

Available online 17-02-2022

\section{Keywords:}

Industrial Pharmacy

Pharmacy Council of India

Academia

Suggestions

\begin{abstract}
A B S T R A C T
In the beginning of 2020, India was hit by corona wave and Pharmacy of the Word, our nation, India had lend a helping hand for entire world. In this context and with the actual industrial practice and the suggested measures are discussed for the academia and Pharmacy Council of India to develop better pharmacy graduates cope up the need of the existing practices in Industrial Pharmacy world.

This is an Open Access (OA) journal, and articles are distributed under the terms of the Creative Commons Attribution-NonCommercial-ShareAlike 4.0 License, which allows others to remix, tweak, and build upon the work non-commercially, as long as appropriate credit is given and the new creations are licensed under the identical terms.
\end{abstract}

For reprints contact: reprint@ipinnovative.com

\section{Covid Wave and India}

In the beginning of 2020 though all were tracking the happenings in Chinese controlled media and US, it was clear that the so call VIRUS infection will be hitting India.

The pandemic declared by WHO, officially made its presence felt in Indian cities from the beginning of Feb2020. March $25^{\text {th }}$ marked day of official Lockdown in India. The bigger questions raised in the mid 2020 were:

1. What is the remedy for this Viral Infection?

2. Can Ritonavir/Lopinavir? Can Ivermectin stop this?

3. Do we have enough Stock of Paracetamol?

4. Is Remdesevir the absolute and final proven remedy?

5. Can we suppress immunity? Dexamethasone is the drug of choice?

6. Hydroxychloroquine the magic bullet?

7. Favipiravir - the desired antiviral?

8. MAbs: Adalimumab? Tocilizumab? Itolizumab? Are these magical bullets?

\footnotetext{
* Corresponding author.

E-mail address: dragnerkar@gmail.com (A. G. Nerkar).
}

9. Will India be able to invent \& produce any Vaccine?

10. Plasma Therapy - will it be a game changer?

11. Do we have enough RT-PCR reagents and tubes for tests?

First wave ended and discussions were on for Vaccines from MNCs and Indian homegrown Vaccine manufacturer. First Wave was lucky to have taken the less toll.

The second wave was deadly Q2-2021, the number of death toll opened few important questions \& observations about the Healthcare, Academia \& General Public too.

1. The dependence of India on China for intermediates and advanced intermediates. China was able to use it as a strategic move and India started getting into it slowly since 2008

2. India Produces so many Pharmacologists, AIIMS but all Indians were hooked to videos from PENCILWALLA DR. about which therapy will be more beneficial

3. Vaccine producer is one part, but design of Vaccine was one area which came as a challenge 
4. If it is from US or EU then it must be good, if it is from India then it may not be that good - Indians failed to hail our homegrown industry

5. AYSUH Drugs and its usage again shown that people are more worried about the memory of phone but not about the dose of a AYUSH drug. Ex. Giloy and Kadhas

6. Differentiation between - Pharmacist, Doctor, Biotecnician, Microbiologist, Epidemiologist, Statistician, Mathematicians, Geneticist, Molecular Biologist was very thin earlier

7. Sterile Manufacturing, GMP, Turnkey Executives for Pharma Projects, scarcity of people was felt

8. Computational Biologists, Clinical Trial Specialist, Genetic Lab Technicians, GCP were few areas recognized as too less in India as man power when to it comes situation like this.

9. Immunologists - a new scarcity was identified as Plasma Therapy was first in for Standard Therapy and then it was removed.

10. Virologists, Microbiologist, Biotechnologists, Geneticist are separate like Finance, Accounting, Cost Accountant in Companies or Program Coder, Program Testing, Main Frame developer, Hardware Engineer in IT was realized even by common people.

The vaccine maker MNC producing product through Indian Vaccine maker and Indigenous Vaccine developers made scientific breakthrough. Software solutions to cater such a large population was relatively difficult yet designed and implemented through COWIN Team. Mammoth 1.15 billion doses were administered!

India is still in Third Wave, though everyone is saying it is getting its peak or getting down but there are lessons learnt and these are for Academia and Pharmaceutical \& Healthcare Industry. Indian Patents Act 1970 and Drug Policy 1978 was a landmark in the History of Indian Pharma. The zeal of entrepreneurs and Scientific acumen in API, Formulation and Manufacturing made India a HUB or PHARMACY of the world. Introduction of Indian Patents Act 2005 as a part of GATT and TRIPS discussion in 1995, concerns of Pharmaceutical Innovators were also addressed. ${ }^{1-5}$

\section{Generic Pharma Market}

The generic drugs market valued at US\$ 390.57 billion in 2020 and is projected to surpass around US\$ 574.63 billion by 2030, growing at a CAGR of $5.59 \%$ from 2021 to 2030

The pharmaceutical industry in India, US $\$ 41.7$ billion by value, world's 3rd largest by overall volume and world's largest as provider of generic medicines globally, with $20 \%$ and $3.5 \%$ share of total global pharmaceutical exports by volume and value respectively to more than 200 countries and territories in 2021 (Wikipedia 2). The Target \& Estimate
Table 1: Global generic drugs market size and estimations, by brand, 2021-2027 (USD Billion) G

\begin{tabular}{|c|c|c|c|c|c|c|}
\hline $\begin{array}{l}\text { Brand } \\
\text { Segment }\end{array}$ & 2021 & 2023 & 2025 & 2027 & \multicolumn{2}{|c|}{$\begin{array}{c}\text { CAGR } \\
(2021-27)\end{array}$} \\
\hline $\begin{array}{l}\text { Branded } \\
\text { Generics }\end{array}$ & 200.60 & 234.66 & 272.41 & 313.86 & 7.75 & $\%$ \\
\hline $\begin{array}{l}\text { Pure } \\
\text { Generics }\end{array}$ & 213.96 & 230.32 & 246.06 & 260.77 & 3.35 & $\%$ \\
\hline Total & 414.56 & 464.98 & 518.45 & 574.63 & 5.59 & $\%$ \\
\hline
\end{tabular}

Table 2: Global generic drugs market size and estimations, by region, 2021-2027 (USD Billion)

\begin{tabular}{lccccc}
\hline Region & $\mathbf{2 0 2 1}$ & $\mathbf{2 0 2 4}$ & $\mathbf{2 0 2 7}$ & \multicolumn{2}{c}{ CAGR } \\
& & & & \multicolumn{2}{c}{$\mathbf{( 2 0 2 1 - 2 7 )}$} \\
North America & 149.46 & 165.00 & 178.77 & 3.03 & $\%$ \\
Europe & 121.34 & 136.67 & 151.47 & 3.77 & $\%$ \\
Asia Pacific & 98.08 & 130.01 & 168.14 & 9.40 & $\%$ \\
Latin America & 29.99 & 38.88 & 49.36 & 8.66 & $\%$ \\
Middle East \& & 15.69 & 20.79 & 26.89 & 9.40 & $\%$ \\
Africa & & & & & \\
Total & 414.56 & 491.35 & 574.63 & 5.59 & $\%$ \\
\hline
\end{tabular}

for Indian Pharma is to reach US \$130 Billion by 2030.

\section{Learning Lessons}

So, what are the learnings, Opportunities and challenges for Indian Pharmaceutical Industry, Academia?

1. Production Linked incentives vs IP driven incentives for Pharmaceutical Sector should be kicked in. Govt has offered Production linked incentives but this will not be sufficient.

2. In the pandemic time India and South Africa fought at WTO for Waiving off the patents. But this is not a good sign for Indian Scientific fraternity. We must and should have IP based products and a capability to quickly make it. Govt should ask Pharma Institutes to have an audit for assessing the patents filed vs commercialized products referring to such patents.

3. PCI and CSIR should encourage cross pollination of knowledge between IIT/ IIM / NIPER / NIT / ICT/ ISERS for topics such as Chemical Engineering, Computational Biology, IT solutions for more efficient solutions in the areas of Research and Development.

4. Indian Academia and Indian Pharma Industry should find out ways to interact with each other. Ex. Genentech (Recomb Biotech) and Caribou Biosciences (CRISPER)

5. Indian Government has been doing their part. It is the time of Industry and Academia to rely on their alumni for help/mentoring as a part of Nation Building

6. Like US-FDA, there can be app for approved products and Adverse event monitoring

7. Common People Should be made aware of achievement of Indian Healthcare and Pharma 
Industry

8. Indian Pharma Alliance \& Pharmacy Council of India should have two annual meetings along with Principal Scientific Advisor to see the changes needed in the Curriculum and need of the Industry.

9. Intellectual Rights, Statistics should be taught to all in Pharmaceutical Post Graduate courses. Upgrade and Pharmaceutical Associations should discuss the extra courses for Students.

10. Startups in In-SILICO DRUG DESIGN and DEVELOPMENT should be encouraged

11. From Relying on US/EU trials - Safety (Toxicology, Mutagenicity) studies should be made part of Curriculum

12. CDSCO, IT companies, NIV, NIC, ICMR should come together to form common platform for Safety and Efficacy studies.

13. Drug Delivery Patents from India by Indian companies should be given - incentives just like Hatch Waxman Act of USA

14. Center of Excellence - Pharmacokinetics for AYUSH, Chemical Drugs to be made

15. IICT, ICT, NIT, NIMHANS - should be have discussion on emotional health and Well being too.

16. Academicians and Industry should have high level discussions with Secretary of Dept of Pharma, TRADE \& Commerce and Principal Scientific Advisor

17. AIIMS, AYUSH \& Excipient Manufacturers, Syringe Manufacturers should be given platform to discuss their needs and express their demands to Pharmaceutical Industry and Academia

18. Safety/ Efficacy trials of homegrown molecules should be the next goal by 2030

\section{Learning Lessons for Academia}

1. Statistics and Mathematics to be introduced to Master's Degree.

2. Rather than blindly following $\mathrm{AI} / \mathrm{ML}$ and creating only Software Hands, Academia can have NASSCOM and IPA platforms to get guidance on TECH side of Indian Pharma.

3. Chemical API manufacturing, Pharmaceutical Product Manufacturing - Industry Visits of Professors should be made must.

4. Analytical Techniques: Protein Analysis, New Techniques should be discussed, interdisciplinary discussion should be encouraged.

5. Last but not the least, Filing commercially attractive Patents and not just fulfilling AICTE demands for Patents.

6. Academia should have Start Up culture in consultation with Govt and State Policy for profit sharing should be discussed.

7. Other Post graduate programs in Pharmaceutical Biology such as Pharmacogenomics should be encouraged by Pharmacy Council of India.

\section{Conflict of Interest}

None.

\section{References}

1. Generic Drugs Market Size to Surpass Around US\$ 574.63 Bn by 2030; 2021. Available from: https://www.globenewswire.com/newsrelease/2021/11/09/2330647/0/en/Generic-Drugs-Market-Size-toSurpass-Around-US-574-63-Bn-by-2030.html.

2. Indian Pharmaceutical Industry and its Contribution; 2020. Available from: https://www.ipa-india.org/blog/indian-pharmaceutical-industryand-its-contribution/.

3. Schemes; 2022. Available from: https://pharmaceuticals.gov.in/ schemes\#: :text=Production\%20Linked\%20Incentive\%20.

4. India, South Africa's patent waiver proposal in WTO achieved tremendous mileage, progression: Commerce Secretary; 2021. Available from: https://www.thehindu.com/news/national/india-southafricas-patent-waiver-proposal-in-wto-achieved-tremendous-mileageprogression-commerce-secretary/article34778668.ece.

5. Zydus granted Orphan Drug Designation by the USFDA for Saroglitazar in the treatment of patients with Primary Biliary Cholangitis (PBC); 2021. Available from: https: //www.zyduscadila.com/public/pdf/pressrelease/Press_Release Zydus_granted_Orphan_Drug_Designation_by_the_USFDA_for_ Saroglitazar_in_the_treatment_of_patients_with_Primary_Biliary_ Cholangitis\%20(PBC).pdf.

\section{Author biography}

A.G. Nerkar, Professor

Cite this article: Nerkar AG. Industrial pharmaceutical scenario. Curr

Trends Pharm Pharm Chem 2022;4(1):1-3. 